\title{
Drug therapy, potential interactions and iatrogenesis as factors related to frailty in the elderly
}

\section{Abstract}

Objective: to investigate the use of drugs, potential drug interactions and iatrogenesis, as factors associated with frailty. Method: an observational, cross-sectional, population-based study of elderly persons registered with the Family Health Strategies of the urban area of a municipal region in the south of Brazil was carried out. The sample was probabilistic and involved 554 elderly persons; and the proportional stratified sampling technique by FHS and gender was used. Data collection was performed in the home, with the gathering of information regarding sociodemographic characteristics and pharmacotherapeutic profile and the evaluation of frailty based on Fried et al. (2001). Results: medications were taken by $86.3 \%$ of the elderly and there was a prevalence of frailty of $63.0 \%$. A total of $39.4 \%$ of the elderly were exposed to polypharmacy, $49.1 \%$ used potentially inappropriate medications and $52.2 \%$ were exposed to potential drug interactions, the most frequent being enalapril and metformin. An association between increased risk of frailty and the variables: polypharmacy; use of potentially inappropriate medications; potential drug interactions; more than two potential drug interactions with the presence or absence of potentially inappropriate medication was identified. Conclusion: an association was found between frailty and polypharmacy, the use of potentially inappropriate medication and the presence of drug interactions. The findings underscore the importance of the monitoring of drug therapy in this population group with a view to the early detection, prevention and resolution of iatrogenesis arising from the use of medicines.

\footnotetext{
Universidade Federal de Santa Maria, Programa de Pós-graduação em Gerontologia. Santa Maria, Rio Grande do Sul, Brasil.

2 Universidade de Cruz Alta, Programa de Pós-graduação em Atenção Integral à Saúde. Cruz Alta, Rio Grande do Sul, Brasil.

3 Universidade Regional do Noroeste do Estado do Rio Grande do Sul, Departamento de Ciências da Vida. Ijuí, Rio Grande do Sul, Brasil.
}

Andressa Rodrigues Pagno ${ }^{1}$

Carolina Baldissera Gross ${ }^{2,3}$

Daiana Meggiolaro Gewehr ${ }^{2,3}$

Christiane de Fátima Colet ${ }^{3}$

Evelise Moraes Berlezi ${ }^{3}$

Keywords: Elderly. Frail Elderly. Pharmaceutical Preparations. Drug Interactions. 


\section{INTRODUCTION}

The aging process of individuals is related to changes in functional capacity, which can be impaired by the presence of chronic diseases and may trigger frailty. The elderly are therefore the age group with the highest prevalence of frailty ${ }^{1-3}$.

One of the main risk factors of frailty among the elderly is the use of medications ${ }^{1}$. Around $70 \%$ to $90 \%$ of the elderly use at least one medication on a daily basis, with an average of two to five drugs prescribed per elderly person ${ }^{4}$.

Although drugs contribute to greater quality of life and life expectancy, their use can generate negative impacts, such as the occurrence of unwanted drug interactions (DI). DIs can impair the efficacy and safety of the proposed treatment, highlighting the importance of this topic and the need to evaluate and monitor problems related to medications ${ }^{5}$. DIs are mainly related to polypharmacy and the use of potentially inappropriate medications (PIM) for the elderly, which can trigger and/or potentiate health problems and exacerbate the condition of frailty $^{2,6}$. The greater the number of drugs used in the treatment of an individual, the greater the probability of the occurrence of iatrogenesis?

The elderly are more vulnerable to undesirable drug-related outcomes, mainly due to the physiological changes caused by senescence, as well as potential DIs, factors that can affect safety and increase patient morbidity and mortality, and which are directly associated with the clinical conditions of the patient ${ }^{6}$. In view of the above, the present study aimed to investigate the use of drugs, potential drug interactions and iatrogenesis as factors associated with frailty.

\section{METHOD}

A cross-sectional, analytical, population-based study was conducted from April to November 2015 in a medium-sized municipal region in the northwest region of the state of Rio Grande do Sul, Brazil. The study population consisted of elderly individuals aged 60 and over, of both genders, assigned to twelve Family Health Strategy (FHS) units in the urban area of the municipal region.
For the sample calculation, the data of the Basic Care Information System (BCIS) was used; the total number of elderly persons enrolled in the FHS in the urban area was 5,269; of this total 2203 (41.8\%) were male and $3056(57.9 \%)$ female. A rate of over 10\% was chosen to represent the elderly population of the FHS. An initial sample of 738 elderly subjects was chosen. It was elected not to use replacements and it was considered that losses of up to $30.0 \%$ would not prejudice the validity of the data. The final sample size for the study was 554 elderly people accounting for $10.53 \%$ of the study population. To achieve greater representation, stratified proportional sampling was used; each ESF was considered a stratum; and men and women were selected proportionally using a simple drawing of lots technique from the list of the elderly persons provided by each unit.

The data of the present study were collected through home-based interviews, using a research instrument composed of a sociodemographic profile questionnaire (age, gender, marital status, education and income) and a modified Dáder Method questionnaire ${ }^{8}$, to characterize the pharmacotherapeutic profile.

The interviews were conducted by five researchers, including the proponents of the study and undergraduates in the area of health, all of whom were previously trained. To identify team qualification and the integrality of the application of the instruments, a pilot test was performed with 30 subjects, who were included in the study population.

The first, second and fifth levels of the Anatomical Therapeutic Chemical Index ${ }^{9}$ (ATC) were used to classify the medications used. For the identification of PIM, the Beers criteria, updated by the American Geriatrics Society, was used ${ }^{10}$.

Potential drug interactions were analyzed and classified in terms of severity using the Micromedex Health Series database ${ }^{11}$. Severity was classified as: a) severe - may be life-threatening and/or require intervention to reduce or avoid serious adverse effects; b) moderate - may result in exacerbation of the health problem and/or require a change in treatment; e c) mild - the interaction would have a limited clinical effect and a major change in treatment is not required. Because of their low risk, interactions of mild severity were not computed in this study. 
The potential effects generated by the interactions were classified in accordance with the first level of the ATC ${ }^{9}$, and the evaluation of the systems and pharmacological class affected by the interaction.

Frailty was evaluated and classified according to the criteria proposed by Fried et $\mathrm{al}^{12}$ : a) Unintentional weight loss in the last year, evaluated by self-report; b) Fatigue evaluated by two self-reported items taken from the Center for Epidemiological Studies Depression (CES-D) Depression Scale validated for application in elderly individuals by Batistoni et al. ${ }^{13}$; c) Hand grip strength, evaluated by an E-Clear EH101 dynamometer; d) Gait speed, which indicates the time, in seconds, that each elderly person takes to walk, at their usual pace, a distance of 4.6 meters; e) Physical activity level, evaluated by means of selfreporting of the weekly frequency and duration of physical exercises and active sport and domestic activities carried out in the week prior to the interview. Individuals with the presence of three to five criteria are considered frail; those with the presence of one or two criteria pre-frail; and those with the absence of criteria pre-frail. For the purposes of statistical analysis, the elderly were allocated into two groups: non-frail elderly; and frail elderly individuals, which included the pre-frail.

A descriptive analysis of the data was initially performed, according to the qualitative and quantitative nature of the variable. To verify the association between frailty and: the number of medications used; the use of PIM and the presence of PIM; potential DI; the Pearson Chi-square hypothesis test was used and risk was calculated using the Odds Ratio (OR). The Statistical Package for the Social Sciences (SPSS) was used to analyze the data. A 5\% level of significance was considered for all the tests.

The present study was designed in accordance with the Regulatory Directives and Guidelines on Research Involving Human Beings in accordance with National Health Council regulation n. 466/2012 and was approved by the Ethics Research Committee of the Universidade Regional do Noroeste do Estado do Rio Grande do Sul under n ${ }^{\circ}$ 1.117.162/2015 and CAAE: 43893915.0.0000.5350.

\section{RESULTS}

The mean age of the elderly in the study was 71.14 ( \pm 8.28 ) years (95\% CI: 70.45-71.83), with a minimum age of 60 years and a maximum of 102 years. The majority of the elderly persons were female, married and with an incomplete elementary education. The sociodemographic characterization is shown in Table 1.

The prevalence of frailty in the study population was $63.0 \%$. In relation to the use of drugs, $86.3 \%$ $(n=478 / 554)$ of the elderly used medication, with a mean of 3.95 ( \pm 3.77 ) (95\% CI, 3.7-4.21) drugs per elderly person; $(n=218 / 554)$ were exposed to polypharmacy, of which $73.9 \%(n=161 / 218)$ were classified as frail; while $49.1 \%(n=272 / 554)$ of the elderly took potentially inappropriate medication, of whom $69.9 \%(n=190 / 272)$ were classified as frail elderly persons. These data are set forth in Table 2 .

Table 1. Sociodemographic characteristics of elderly persons registered with the Family Health Strategies of the urban area of the municipal region of Ijuí, Rio Grande do Sul, 2017. (N=554).

\begin{tabular}{lll}
\hline Categories & Total & $\%$ \\
\hline Gender & & \\
Female & 337 & 60.8 \\
Male & 217 & 39.0 \\
\hline Marital status & & \\
Married & 326 & 58.8 \\
Widowed & 141 & 25.5 \\
Single & 29 & 5.2 \\
Divorced & 29 & 5.2 \\
Civil Union & 29 & 5.2 \\
\hline
\end{tabular}


Continuation of Table 1

\begin{tabular}{lll}
\hline Categories & Total & $\%$ \\
\hline Years of schooling & & 10.8 \\
0 & 60 & 75.1 \\
Up to 8 & 416 & 10.1 \\
$8-11$ & $57)$ & 3.8 \\
$>11$ & 21 & \\
Household Arrangements & & 63.4 \\
Spouse & 351 & 15.9 \\
Children & 88 & 14.3 \\
Alone & 79 & 3.2 \\
With other relatives & 18 & 2.2 \\
Non-family members & 12 & 1.1 \\
Grandchildren / Great grandchildren & 6 & \\
Family income & & 66.8 \\
1 to 3 MW* & 370 & 16.6 \\
3.1 to 5.0 MW & 92 & 11.6 \\
$<1.1$ MW & 64 & 3.4 \\
5.1 to 10 MW & 19 & 1.6 \\
$>10$ MW & 9 & \\
\hline
\end{tabular}

*MW: minimum wage. 1 MW equivalent to R\$ 788.00 (2015).

Table 2. Relative and absolute frequencies of variables related to medications and association with frailty. $(\mathrm{N}=554)$. Ijuí, RS, 2017.

\begin{tabular}{|c|c|c|c|c|}
\hline Variable & $\begin{array}{l}\text { Non-frail elderly } \\
\%(\mathrm{n})\end{array}$ & $\begin{array}{l}\text { Frail elderly } \\
\%(\mathrm{n})\end{array}$ & $\mathrm{p}$ & OR (CI95\%) \\
\hline \multicolumn{5}{|c|}{ Use of medications } \\
\hline Use & $35,8(171)$ & $64,2(307)$ & 0,13 & $1,45(0,89-2,37)$ \\
\hline Don't use & $44,7(34)$ & $55,3(42)$ & & \\
\hline \multicolumn{5}{|l|}{$\begin{array}{l}\text { Quantity of } \\
\text { medications }\end{array}$} \\
\hline$<5$ & 44,0 (148) & $56,0(188)$ & 0,00 & $2,24(1,53-3,22)$ \\
\hline$\geq 5$ & $26,1(57)$ & $73,9(161)$ & & \\
\hline \multicolumn{5}{|l|}{$\mathrm{PIM}^{* *}$} \\
\hline Don't use & $43,6(123)$ & $56,4(159)$ & 0,00 & $0,55(0,39-0,79)$ \\
\hline Use & $30,1(82)$ & 69,9 (190) & & \\
\hline \multicolumn{5}{|l|}{$\mathrm{DI}^{*}$} \\
\hline No DI $(=0)$ & 42,6 (113) & $57,4(152)$ & 0,00 & $1,59(1,12-2,25)$ \\
\hline$\geq 1 \mathrm{DI}$ & $31,8(92)$ & $68,2(197)$ & & \\
\hline \multicolumn{5}{|c|}{ DI with presence of PIM } \\
\hline$\leq 2$ interactions & $33,6(74)$ & $66,4(146)$ & 0,01 & $2,78(1,24-6,22)$ \\
\hline$>2$ interactions & $15,4(8)$ & $84,6(44)$ & & \\
\hline
\end{tabular}

*Drug Interaction; **Potentially inappropriate medication for the elderly.

An association between polypharmacy and frailty was identified. The risk of frailty was twice as high among those who used more than five drugs. An association was also observed between the use of potentially inappropriate medications and frailty.
In terms of potential DI, an average of $1.75( \pm 2.82)$ interactions per subject was identified, while $52.2 \%$ ( $n=289 / 554)$ of the elderly had a risk of DI. Of these, $68.2 \%$ ( $n=197 / 289$ ) were from the frail elderly group, with an association between susceptibility to 
potential DI and frailty; the OR showed that elderly persons subject to drug interactions had a $52.0 \%$ greater chance of frailty.

We also analyzed potential DI with the presence of PIM. It was found that $19.1 \%(n=52 / 554)$ of the elderly experienced more than two interactions involving PIM; of these $84.6 \%(n=44 / 52)$ were frail; with a statistically significant difference between frailty and being subject to DI with PIM. The OR shows that there was an almost three times greater chance of frailty among users with more than two DIs involving PIM.

It was observed that of the 289 elderly individuals exposed to potential DI, 77.1\% ( $\mathrm{n}=101 / 289)$ had one to two DI and were frail. An association was also observed between the number of MIs and frailty ( $p$ $<0.01$ ) and the chances of frailty were twice as great among the elderly with more than two interactions $(\mathrm{OR}=2.17,95 \% \mathrm{CI}, 1.29-3.64)$.
Table 3 evaluates the elderly classified as frail, and shows the DI among the most frequent PIM identified among them. In the frail elderly, there was a higher frequency of: Enalapril x Metformin; Acetyl Salicylic Acid (ASA) x Enalapril; and Hydrochlorothiazide (HCTZ) x ASA. However, a statistically significant association was only identified between frailty and the potential interaction between Calcium x HCTZ, among frail elderly persons.

In contrast, when observing the association between frail elderly persons with DI including PIM, a statistically significant association was observed with the drugs Digoxin x Omeprazole.

Table 3 shows that the cardiovascular system is the most affected by potential DI, most frequently with moderate and/or severe severity; while the blood system was the most affected by PIM, with a predominance of severe interactions.

Table 3. Drug Interactions and Potentially Inappropriate Medications Associated with Frail Elderly Persons registered with the ESF in the municipal region of Ijuí, Rio Grande do Sul, 2017. (N = 554).

\begin{tabular}{|c|c|c|c|c|c|c|}
\hline Interactions & Severity & Outcome & $\begin{array}{l}\text { System Affected } \\
\left(\text { ATC* }^{*}\right)\end{array}$ & $\begin{array}{l}\text { Prevalence of } \\
\text { interactions } \\
\%(n)\end{array}$ & $\mathrm{p}$ & $\mathrm{OR}^{* *}(\mathrm{CI} 95 \%)$ \\
\hline $\begin{array}{l}\text { Enalapril X } \\
\text { Metformin }\end{array}$ & Moderate & $\begin{array}{l}\text { Increased risk of } \\
\text { hypoglycemia }\end{array}$ & $\begin{array}{l}\text { Metabolic and } \\
\text { Digestive and } \\
\text { Nervous }\end{array}$ & $8.8(49)$ & 0.11 & $0.58(0.30-1.13)$ \\
\hline $\begin{array}{l}\text { AAS }^{* * *} \mathrm{X} \\
\text { Enalapril }\end{array}$ & Moderate & $\begin{array}{l}\text { Decreased efficacy of } \\
\text { Antihypertensive }\end{array}$ & Cardiovascular & $8.8(49)$ & 0.50 & $0.81(0.43-1.51)$ \\
\hline $\begin{array}{l}\mathrm{HCTZ}^{* * * *} \mathrm{X} \\
\text { AAS }\end{array}$ & Severe & $\begin{array}{l}\text { Decreased Efficacy of } \\
\text { Diuretic and Possible } \\
\text { Nephrotoxicity }\end{array}$ & $\begin{array}{l}\text { Cardiovascular } \\
\text { and Genitourinary }\end{array}$ & $8.1(45)$ & 0.13 & $0.59(0.30-1.18)$ \\
\hline $\begin{array}{l}\text { Enalapril X } \\
\text { Furosemide }\end{array}$ & Moderate & Postural Hypotension & Cardiovascular & $2.2(16)$ & 0.12 & $0.38(0.10-1.36)$ \\
\hline Calcium X HCTZ & Moderate & $\begin{array}{l}\text { Increased risk of } \\
\text { hypercalcemia }\end{array}$ & $\begin{array}{l}\text { Cardiovascular. } \\
\text { Metabolic and } \\
\text { Digestive }\end{array}$ & $2.3(13)$ & 0.02 & $0.13(0.01-1.06)$ \\
\hline \multicolumn{7}{|c|}{ Potentially Inappropriate Medication } \\
\hline $\begin{array}{l}\text { Digoxin X } \\
\text { Omeprazole }\end{array}$ & Moderate & Digital Toxicity & $\begin{array}{l}\text { Cardiovascular. } \\
\text { Metabolic and } \\
\text { Digestive }\end{array}$ & $1.6(9)$ & 0.02 & $1.60(1.50-1.71)$ \\
\hline $\begin{array}{l}\text { Amitriptyline X } \\
\text { Ibuprofen }\end{array}$ & Severe & $\begin{array}{l}\text { Increased risk of } \\
\text { bleeding }\end{array}$ & Blood & $0.9(5)$ & 0.42 & $0.42(0.04-3.80)$ \\
\hline $\begin{array}{l}\text { Alprazolam X } \\
\text { Omeprazole }\end{array}$ & Moderate & $\begin{array}{l}\text { Benzodiazepine } \\
\text { toxicity }\end{array}$ & Nervous & $0.5(3)$ & 0.89 & $0.85(0.07-9.43)$ \\
\hline $\begin{array}{l}\text { Diclofenac X } \\
\text { Ibuprofen }\end{array}$ & Severe & Risk of hemorrhage & Blood & $0.6(2)$ & 0.27 & $1.59(1.49-1.69)$ \\
\hline
\end{tabular}

*Anatomical Therapeutic Chemical Index; ** Odds Ratio; *** Acetylsalicylic acid; **** Hydrochlorothiazide. 
Table 4 shows the association between the systems most affected by potential interactions and frailty.
There was no statistically significant association between the affected systems and frailty.

Table 4. Association between systems affected by potential drug interactions and frailty of elderly people registered with FHS. Ijuí, Rio Grande do Sul, 2017. (N=554).

\begin{tabular}{|c|c|c|c|c|}
\hline Variable & $\begin{array}{l}\text { Non-frail Elderly } \\
\% \text { (n) }\end{array}$ & $\begin{array}{l}\text { Frail Elderly } \\
\% \text { (n) }\end{array}$ & $\mathrm{p}$ & OR* $(\mathrm{CI} 95 \%)$ \\
\hline \multicolumn{5}{|c|}{ Cardiac System } \\
\hline Yes & $39.1(79)$ & $60.9(123)$ & 0.35 & $1.28(0.75-2.17)$ \\
\hline No & $33.3(29)$ & $66.7(58)$ & & \\
\hline \multicolumn{5}{|c|}{ Nervous System } \\
\hline Yes & $42.7(44)$ & $57.3(59)$ & 0.16 & $1.42(0.86-2.33)$ \\
\hline No & $34.4(64)$ & $65.6(122)$ & & \\
\hline \multicolumn{5}{|c|}{ Metabolic and Digestive System } \\
\hline Yes & $37.2(54)$ & $62.8(91)$ & 0.96 & $0.98(0.61-1.59)$ \\
\hline No & $37.5(54)$ & $62.5(90)$ & & \\
\hline \multicolumn{5}{|c|}{ Blood System } \\
\hline Yes & $28.3(17)$ & $71.7(43)$ & 0.10 & $0.6(0.32-1.11)$ \\
\hline No & $39.7(91)$ & $60.3(138)$ & & \\
\hline \multicolumn{5}{|c|}{ Genitourinary System } \\
\hline Yes & $45.2(28)$ & $54.8(34)$ & 0.15 & $1.51(0.85-2.67)$ \\
\hline No & $35.2(80)$ & $64.8(147)$ & & \\
\hline \multicolumn{5}{|c|}{ Musculoskeletal System } \\
\hline Yes & $30(12)$ & $70(28)$ & 0.29 & $0.68(0.33-1.40)$ \\
\hline No & $38.6(96)$ & $61.4(153)$ & & \\
\hline
\end{tabular}

* Odds Ratio

\section{DISCUSSION}

The prevalence of frail elderly in this study was $63 \%$, whereas in the Frailty among the Brazilian Elderly (FIBRA) ${ }^{3}$ study it was around $60 \%$. Pegorari and Tavares ${ }^{2}$ identified that $68.2 \%$ of the elderly studied had at least one criterion that determining frailty, with $12.8 \%$ frail and $55.4 \%$ pre-frail. Buranelo et al. ${ }^{1}$ found that $11.1 \%$ of the elderly were frail and $46.3 \%$ were pre-frail, accounting for $57.4 \%$ of individuals.

The results of the present study demonstrate the significant consumption of drugs by the elderly, which is an important factor in relation to frailty. Also related to this condition is the use of polypharmacy and the presence of PIM. The association between frailty and polypharmacy has been demonstrated in other studies ${ }^{2,14-17}$, as has the association with $\mathrm{PIM}^{16,18}$. A relationship between frailty and polypharmacy was found in the present study, agreeing with other studies that used the same methodology to establish the frailty phenotype $\mathrm{e}^{14,16}$
Aging predisposes the individual to an increased risk of adverse health events. Elderly patients with a higher number of associated diseases may require more medication, as evidenced in another study ${ }^{17}$. The chance of being frail as opposed to robust was significantly higher in elderly persons with cognitive decline, postural instability and who were subject to polypharmacy. This same study found a three times greater risk among elderly people subject to polypharmacy. It is understood that in the process of becoming frail the clinical, physical and cognitive conditions are related to an increase in the use of medicines.

An association between the use of PIM and frailty was also revealed by the results of the present study. Similar results have been found in literature ${ }^{16,18}$. In clinical application, PIM can aggravate the clinical picture of the elderly, affect quality of life; and increase the risk of potentially serious and fatal events ${ }^{10}$.

The presence of PIM, as well as the high number of drugs used in pharmacological treatment, tend to 
leave frail elderly individuals prone to negative events, such as an increased risk of adverse effects, mostly from DI. In this context, the present study found that the prevalence of frailty was greater when PIM were used in potential DI. These relationships can be explained by the changes and characteristics present in frail elderly people that make them more vulnerable to manifestations of DI and health problems resulting from the same $e^{6,15}$. It should also be pointed out that the cross-sectional design of the present study makes the establishing of a causal relationship with the outcome of DI among the elderly impossible.

The metabolism of drugs is slower during senescence, which results in the greater concentration and action of the drug in the body due to the decrease in hepatic and renal clearance and a reduction in blood flow; which results in the low extraction rate for the drug ${ }^{19}$. In addition to metabolization, the diminished capacity of the homeostatic reserve of the body can cause a decline in functions and increase the sensitivity of some drugs; which increases the exposure time of the drug in the body and thus increases the risk of $\mathrm{DI}^{20}$.

Potential DI arising from the pharmacodynamic and pharmacokinetic modifications of drugs in the elderly body together with the use of a combination of several drugs have been widely explored in literature ${ }^{21}$. However, most of these studies do not consider frailty to be a factor associated with potential drug interactions. In this context, the integrative review by Rodrigues and Oliveira ${ }^{21}$ on the occurrence of drug interactions and adverse drug reactions specifically among the elderly found that none of the 49 studies analyzed evaluated the frailty phenotype as an associated variable, although the interactions were related to frail conditions such as reduced functional capacity, falls, chronic diseases and geriatric syndromes.

When the specific DI associated with frailty in the elderly in this study is observed, it is highlighted that the most frequent potential DI was between Enalapril and Metformin, the outcome of which is an increased risk of the occurrence of hypoglycemia ${ }^{11}$, with the potential to decompensate the metabolism of the elderly, especially among those considered frail, due to their low capacity for dealing with stressors ${ }^{22}$. Very low levels of glucose and cardiovascular complications in the body can trigger problems related to the cardiovascular system and central nervous system, such as: risk of acute myocardial infarction, strokes and syncope vagal vessel ${ }^{22}$.

In addition to these effects, DI between Enalapril and Metformin may cause reduced strength, decreased walking time and changes in body balance, such as dizziness and consequently falls ${ }^{22,23}$. The study by Marcum et al. ${ }^{23}$ found that falls were a result of negative events involving angiotensin converting enzyme (ACE) inhibitors. As well as leading to possible physical frailty, falls are related to psychological problems, such as depression and isolation. It is suggested, therefore, that these can function as a triggering event, precipitating the cycle of frailty. Furthermore, when occurring in an already frail body, the iatrogenesis triggered can be correlated with frailty, as a cause and effect, which can be avoided with proper management of the use of the medicines in question.

The interaction between Angiotensin Converting Enzyme Inhibitors (Enalapril) and oral antidiabetic agents (Metformin) had no statistically significant association with frailty in this study, but its frequency of occurrence among frail elderly patients should be considered, along with the iatrogenic complications of the same.

However, the drug interaction between Calcium and HCTZ, the outcome of which hypercalcemia ${ }^{11}$, had a statistically significant relationship with frailty. Elderly patients, especially the most debilitated, are more prone to the symptoms of drug interactions, which include anorexia, muscle weakness, disorientation and progressive lethargy ${ }^{24}$. Such characteristics associated with frailty can influence and have serious consequences for the clinical picture of the elderly, intensifying the aggravation of the process. Unintentional weight loss due to anorexia and the reduction of strength has a causal relationship with the indication of frailty.

The interaction involving drugs considered inappropriate for elderly people and used most frequently and which had an association with frailty was between Digoxin and Omeprazole. This interaction predisposes the body to increase the absorption of digoxin as a consequence of the increase of the gastric $\mathrm{pH}$, followed by a decrease in the hydrolysis of the digoxin, and alterations in its metabolism that when combined with the 
reduced renal clearance of the elderly results in an outcome of digitalis toxicity ${ }^{11,25}$. As it has a narrow therapeutic index; and when dealing with frail elderly persons, the interaction involving digoxin may be potentially significant.

Symptoms of digoxin poisoning are often confused with other diseases, making its diagnosis difficult and delayed. In the frail elderly there may be an increased risk related to health complications, infections and disabilities, demonstrating the need for patient monitoring when using digoxin

While the most common potential specific interactions among frail elderly persons affect several organic systems, the cardiovascular system is most frequently affected by negative events due to potential interactions in the context of such individuals. Another study has already found similar results ${ }^{26}$ without considering the phenotype of frailty.

Moreover, it is important to highlight that of the nine most frequent drug interactions found in the present study, six involved drugs classified by ATC as cardiovascular, agreeing with the findings of Somers et $\mathrm{al}^{27}$. The high frequency of coronary diseases and hypertension among the elderly ${ }^{28}$ can explain the use of this medication class and consequently the greater risk of negative outcomes and interactions related to the cardiac system.

It is therefore important to identify the medications, their impact and the risk of interactions in the context of frailty in order to promote health care among the elderly. However, the design of the present study did not allow the monitoring and evaluation of the variables studied in the health of the elderly and the possible impacts of the drug treatment. However, these data highlight the importance of pharmaceutical care on a continuous basis and with systematic evaluations that can allow the early identification of the adverse effects of medications and their impact on the health of the elderly; and thus prevent the complications that arise from iatrogenesis and their impacts on the physical, functional and cognitive capacities that can intervene in the process of becoming frail.

\section{CONCLUSION}

In summary, there was a high consumption of medications by the elderly involved in the study, as well as the use of polypharmacy and potentially inappropriate drugs and the association of these with frailty.

It is important to consider not only the use of medications, but also the events resulting from drug therapy and its negative outcomes, as cause and effect related factors in the health-disease process of the elderly, especially those debilitated by the susceptibility presented.

Further studies regarding the risks/benefits of the treatment used by the elderly and their relationship with the frailty syndrome are suggested, in order to better define criteria that may help health professionals involved in continuous care and facilitate systematic evaluations that allow the early identification of adverse drug events and impacts on the health of the elderly; and thus prevent the complications arising from iatrogenesis and their impacts on the physical, functional and cognitive capacities that can intervene in the process of becoming frail among the elderly.

\section{REFERENCES}

1. Buranello MC, Pegorari MS, de Castro SS, Patrizzi LJ. Síndrome de fragilidade em idosos da comunidade: características socioeconômicas e de saúde: um estudo observacional. Medicina (Ribeirão Preto). 2015;48(5):431-9.

2. Pegorari MS, Tavares DMS. Fatores associados à síndrome de fragilidade em idosos residentes em área urbana. Rev Latinoam Enferm. 2014;22(5):874-82.

3. Neri AL, Yassuda MS, de Araújo LF, Eulálio MDC, Cabral BE, Siqueira MEC De, et al. Metodologia e perfil sociodemográfico, cognitivo e de fragilidade de idosos comunitários de sete cidades brasileiras: Estudo FIBRA. Cad Saúde Pública. 2013;29(4):778-92.

4. Bezerra TA, de Brito MAA, Costa KNFM. Caracterização do uso de medicamentos entre idosos de uma unidade do Programa Saúde da Família. Cogitare Enferm. 2016;21(1):1-11. 
5. Tasso D, Augusto C, Campos M, Andrighetti LH, Perassolo MS. Possíveis interações medicamentosas em pacientes polimedicados de Novo Hamburgo, RS, Brasil. Infarma. 2017;30(1):21-9.

6. Secoli SR. Polifarmácia: interações e reações adversas no uso de medicamentos por idosos. Rev Bras Enferm. 2010;63(1):136-40.

7. Manso MEG, Biffi ECA, Gerardi TJ. Prescrição inadequada de medicamentos a idosos portadores de doenças crônicas em um plano de saúde no município de São Paulo , Brasil. Rev Bras Geriatr Gerontol. 2015;18(1):151-64.

8. Hernández DS, Dáder MJF, Castro MMS. Método Dáder: Manual de Seguimento Farmacoterapêutico. $3^{\mathrm{a}}$ ed. Lisboa: Edições Universitárias Lusófonas; 2009.

9. World Health Organization, Collaborating Centre for Drug Statistics Methodology. Anatomical Therapeutic Chemical ATC/DDD Index, 2016 [Internet]. Geneva: WHO; 2016 [acesso em 23 out. 2016]. Disponível em: http://www.whocc.no/atc_ddd_index/

10. American Geriatrics Society. American Geriatrics Society 2015 Updated Beers Criteria for Potentially Inappropriate Medication Use in Older Adults. J Am Geriatr Soc. 2015;63(11):2227-46.

11. Micromedex ${ }^{\circledR}$ Healthcare Series [Internet]. Greenwood Vilage: Thomson Healthcare; 2016 [acesso em 10 out. 216]. Disponível em: www. micromedex.com

12. Fried LP, Tangen CM, Walston J, Newman AB, Hish $\mathrm{C}$, Gottdiener J, et al. Frailty in older adults: evidence for a phenotype. J Gerontol Ser A Biol Sci Med Sci. 2001;56(3):146-56.

13. Batistoni SS, Neri AL, Cupertino APFB. Validade da escala de depressão do Center for Epidemiological Studies entre idosos Brasileiros. Rev Saúde Pública. 2007;41(4):598-605.

14. de Araújo PL, Galato D. Risco de fragilização e uso de medicamentos em idosos residentes em uma localidade do sul de Santa Catarina. Rev Bras Geriatr Gerontol. 2012;15(1):119-26.

15. Vieira RA, Guerra RO, Giacomin KC, Vasconcelos KSS, Andrade ACS, Pereira LSM, et al. Prevalência de fragilidade e fatores associados em idosos comunitários de Belo Horizonte, Minas Gerais, Brasil: dados do estudo FIBRA. Cad Saúde Pública. 2013;29(8):1631-43.

Received: June 02, 2018

Reviewed: July 20, 2018

Accepted: September 03, 2018
16. Cassoni TCJ, Corona LP, Romano-Lieber NS, Secoli SR, Duarte YAO, Lebrão ML. Uso de medicamentos potencialmente inapropriados por idosos do Município de São Paulo, Brasil: Estudo SABE. Cad Saúde Pública. 2014;30(8):1708-20.

17. Closs VE, Ziegelmann PK, Gomes I, Schwanke CHA. Frailty and geriatric syndromes in elderly assisted in primary health care. Acta Sci Health Sci. 2016;38(1):9-18.

18. Cullinan S, O’Mahony D, O’Sullivan D, Byrne S. Use of a frailty index to identify potentially inappropriate prescribing and adverse drug reaction risks in older patients. Age Ageing. 2016;45(1):115-20.

19. McLachlan AJ, Pont LG. Drug metabolism in older people: a key consideration in achieving optimal outcomes with medicines. J Gerontol Ser A Biol Sci Med Sci. 2012;67(2):175-80.

20. Silva R, Schmidt O, Silva S. Polifarmácia em geriatria. Rev AMRIGS. 2012;56(2):164-74.

21. Rodrigues MCS, de Oliveira C. Drug-drug interactions and adverse drug reactions in polypharmacy among older adults: an integrative review. Rev Latinoam Enferm. 2016;24(1):1-17.

22. Tavares MDS, Macedo TC, Ribeiro D, Mendes G. Possíveis interações medicamentosas em um grupo de hipertenso e diabético da Estratégia Saúde da Família. REVISA. 2012;(61):119-25.

23. Marcum ZA, Amuan ME, Hanlon JT, Aspinall SL, Handler SM, Ruby CM, et al. Prevalence of unplanned hospitalizations caused by adverse drug reactions in older veterans. J Am Geriatr Soc. 2012;60(1):34-41.

24. Beers MH, Ouslander JG, Rollingher I, Reuben DB, Brooks J, Beck JC. Explicit criteria for determining inappropriate medication use in nursing home residents. Arch Intern Med. 1991;151(9):1825-32.

25. Rang HP, Dale MM, Ritter JM, Flower RJ, Henderson G. Farmacologia. $7^{\mathrm{a}}$ ed. Rio de Janeiro: Elservier; 2012.

26. Neto PRO, Nobili A, de Lyra DP, Pilger D, Guidoni $\mathrm{CM}$, de Oliveira AB, et al. Incidence and predictors of adverse drug reactions caused by drug-drug interactions in elderly outpatients: A prospective cohort study. J Pharm Pharm Sci. 2012;15(2):332-43.

27. Somers A, de Paepe P, Maele G Van. Evaluation of clinical pharmacist recommendations in the geriatric ward of aBelgian Unibersity hospital.pdf. Clin Interv Aging. 2013;8:703-9.

28. Santos GS, Olm Cunha ICK. Fatores associados ao consumo de medicamentos entre idosos de uma unidade básica de saúde. REFACS. 2017;5(2):191-9. 